\title{
Diagnosis of Insect Pests and Diseases of Apiary, Vegetable and Fruit Crops
}

\author{
Ashok S. Yadav*, S.P. Singh and Pradyumn Singh \\ RVSKVV-KrishiVigyan Kendra, Morena-476001(M.P.) India \\ *Corresponding author
}

\section{Keywords \\ Diagnosis, Insect pests, Diseases, apiary, Vegetable, Fruit crops, Food security}

\section{Article Info}

Accepted:

11 June 2020 Available Online: 10 July 2020

\section{A B S T R A C T}

\begin{abstract}
The main objective of Krishi Vigyan Kendra (KVK) is to help the farmers in the command area in the field of Agriculture and allied sectors. During the last 4 years i.e. from 2014 to 2018, a record of all the visiting farmers was maintained in the plant health diagnostic section at KVK, in which complete details of the farmers with address and contact number was maintained. Similarly, the purpose of visiting KVK was recorded date wise by the KVK Plant Protection Scientist and at the end of each month; a summary was prepared and analyzed for severity of the attack of insect pest and diseases. It was found that 15.53 percent farmers started enquiring about the apiary and its management technology in the month of August because rabi season is the main period for starting apiculture. In the month of September, October, November, December, January, February, March, April, May, June and July 10.68, 8.74, 11.65, 10.68, 13.59, 3.88, 1.94, 5.82, 7.77, 2.91 and 9.71 percent farmers respectively visited the KVK to acquiring Scientific apiculture and its insect pest and disease management. 52.05 and 42.47 percent farmers inquiring the management of late blight and leaf curl (white fly) of Potato. In Tomato crop 73.68, 15.79 and 10.53percent farmers visited for control of white fly, fruit borer and late blight respectively. 71.43 and 28.57 percent farmers know about management of the leaf curl of chilli and shoot and fruit borer of brinjal. In fruit crops viz; Papaya leaf curl 34.78 percent, Guava mealy bug 21.74 percent, Jackfruit mealy bug 26.08 percent and Citrus cancer 17.39 percent farmers inquiring about its management.
\end{abstract}

\section{Introduction}

Krishi Vigyan Kendra (KVK), a district level institution established under the administrative control of three different organizations namely SAUs, ICAR, National Institutes and Non government agencies. To feed the ever-growing populations, we have to double the production to meet the food requirements of the people, by adopting innovative technology, which is not an easy task as arable land is shrinking. Further, all our efforts get jeopardized due to unprecedented threat by a large number of insect-pest, disease, weeds and several environmental stresses causing approximately 40 percent reduction in yield worldwide, primarily due to want of timely diagnosis and advisory support. Saving even 1percent loss can feed the million (Oerke et al., 1994). In order to deliver timely diagnosis to farmers, plant health clinic has been play important 
role in district place/ KVKs in India. Plant Clinics are all about plant health and the major role of plant Clinic lies in diagnosis and advisory.

Morena district is divided into 07 major blocks namely Morena, Joura, Kailaras, Sabalgargh, Pahadgargh, Ambah and Porsa. Each block is known for its specific cropping pattern. Block Morena haspearlmillet-wheat, pearlmillet-mustard, paddy-wheat cropping pattern on major part of its land.In Joura block, the cropping pattern is pearlmilletmustard-berseem, pearlmillet-wheat, paddywheat and pearlmillet-sweet pea-wheat. A wide variety of vegetables are also grown like chilli, tomato, potato, brinjal, ladyfinger, muskmelon, bitter guard, pumpkin, methi, bottle guard, cucumber. Farmers are also grown Guava and citrus fruits crops with beekeeping. Kailars and Sabalgargh blocks are known for pearlmillet-mustard-berseem cropping rotation with beekeeping. In Pahadgarh block, pearmillet-wheat/blackgram is the main crop rotation.

In Ambah and Porsa block pearl milletwheat/gram/mustard, sesamewheat/mustard/gram are the main crop rotation while some of the area is under potato-wheat, pearlmillet-potato crop rotation. Hence it can be summarized that district Morena has rich food plant biodiversity because all the crops are grown in the district. It was noticed while working with farmers that in spite of tremendous progress made by the farmers of Madhya Pradesh, still there was a wide gap between the potential of the technology and the achieved results by the farmers. Singh (2013) indicated that most of the recommended brands of the pesticides were not available in the market. As a result of which farmers were helpers in adopting the recommended spray schedule for the control of attack of various insect pest and diseases on various crops. The attack of insect pests and disease is season specific. The same crop maybe attacked severely by one insect pest or disease in one year and in the other year some other insect pest or disease maybe prevalent on the same crop in severe form. At the same time, attack of one insect pest in severe form may occur year on the same crop as is the case attack of Grass hopper on pearlmillet in the Morena district during 2016 and 2018 and also Bristle beetle on pearl millet during 2018.A large number of farmers visited KVK, Morena every year to have guidance from Scientists posted at the centre. Therefore, it was planned to ascertain the areas in which farmers made most of the queries so that the Kendra can make changes in the action plan so that maximum farmers can be benefitted. More ever, it is a known fact that for each $\mathrm{KVK}$, there is no uniform syllabus and it depends upon the requirement of the farming community of that area. Keeping in view the above facts, it was planned to classify the data pertaining to number of farmers who visited KVK campus in the plant disease diagnostic/plant health clinic pertaining to apiary, vegetable, horticulture, cereals, pulses and oilseeds to get the problem solved with the advice of Scientist posted at the KVK.

\section{Materials and Methods}

Present study was conducted at RVSKVVKrishi Vigyan Kendra, Morena (M.P.) during 2014-2018. Record of all visiting farmers was maintained in the plant health diagnostic section at KVK, in which complete detail of the farmers with address and contact number was maintained. Similarly, the purpose of visiting KVK was recorded date wise by the KVK Plant Protection Scientist and at the end of each month, a summary was prepared and analyzed month wise, problem wise and crop wise to note down the extent of damage caused by the insect pests, diseases or other agencies on Apiary, vegetables and fruit crops. 


\section{Results and Discussion}

The results of present studies were given in table 1,2,3,4 and 5 .

\section{Apiary (Beekeeping)}

Beekeeping (Apiculture) was once a very flourishing industry with very few minor disease and insect pests (Chaudhary, 2014). Beekeeping is important agriculture related practice for livelihood security and employment generation of rural youth, small and marginal farmers in Chambal region of Madhya Pradesh. The 103 farmers were visited KVK for acquiring scientific information of beekeeping and management of insect pest and disease of apiary like wax moth, mite, predator and brood diseases (Table 1). Result of study indicated that out of 103 bee farmers who visited KVK campus, the minimum percent value $(1.94 \%)$ in the month of March and maximum (15.53\%) in month of August. The percent value of farmers visited at KVK for the month of September, October, November, December, January and February were 10.68, 8.74, $11.15,10.68,13.59$ and 3.88 respectively. Continuous arrival of bee farmers in the KVK campus indicated that farmers was more cautious about getting scientific information of insect pest, predator and disease management of apiary. Farmers were getting information before and after migration of bee colonies.

Honey bee diseases and pests based on their damage to life stages of honey can be broadly classified into-brood and adult diseases with the exception of Varroa destructor, T. clareae which affect both the stages. In India as Madhya Pradesh, V. destructor, is the major problem followed by European foulbrood (EFB) and wax moth. Diagnosis of bee diseases, pests, parasites and other abnormalities are an important part of beekeeping. Apiary inspector and beekeepers must be able to recognize bee diseases, pests and parasites and to differentiate the serious diseases from the less important ones (Hachiro Shimanuki and David A. Knox, 2000).

\section{Potato}

Data (Table 2) showed that out of 73 farmers who visited KVK campus, percent value for the month of August, September, October, November, December, January and February was $16.67,0.0,19.50,19.42,6.73,31.83$ and 5.85 respectively. Continuous arrival of the farmers in the KVK campus in each month indicated that this crop is being attacked by insect pest and disease its whole growing period.

\section{Infestation of whitefly Bemasia tabaci (Leaf curl disease)}

It is pertinent to mention that nymph and adult does the damage suck the cell sap of leaves and leaves curled down. It was transmitted leaf curl viruses in the potato crop. It was found that damage to the crop was very severe in the months of January and 61.29 percent farmers visited the KVK. This pest is again of great concern and is difficult to control at the farmers own level as well as at the pesticide dealers level who mainly advice to the farmers to go for cocktailing spray of insecticides and spraying of synthetic pyrethroids in the potato crop.

\section{Incidence of late blight disease (Phytophthora infestans)}

Late blight has been identified as a major disease of tomato and potato and is one of the most devastating plant diseases of all time. Late blight can quickly devastate tomato and potato crops at any time during plant ontogeny. Late blight is the severe problem in 
all potato growing areas in the country and Chambal region of Madhya Pradesh. Late blight disease incidence was start in the month of October and active up to month of February. It was severe in the month of November and January and 42.11 and 34.21 percent farmers arrived in the $\mathrm{KVK}$ for disease diagnosis. The climatic condition was congenial for disease development in the month of November and January. Farmers of the region were more active for disease diagnosis and control measures.

In potato crop 5.48, 52.05 and 42.47 percent farmers were visited $\mathrm{KVK}$ for preventing measures before sowing, late blight incidence management and white fly transmitted leaf curl viruses disease control respectively from August to February.

\section{Tomato}

Tomato (Lycopersicon esculentum Mill.) is one of the most economically important vegetable crops in the world. Results (Table 3) revealed that tomato crop was prone to the attack of insect pest and disease as the farmers enquired about the management information at the centre. Percent value of sample diagnosed during the month of February, March, April, May, June, July, August and September was 4.76,24.60, $37.30,16.67, \quad 11.90, \quad 0.0, \quad 2.38$ and 2.38 respectively.

\section{Leaf curl virus disease}

Among the major biotic constraints, virus associated Tomato leaf curl disease (ToLCD) is a major limiting factor affecting its cultivation and yield of Tomato crops. Different symptoms associated with disease are reported such as leaf curling, puckering of leaves, vein yellowing, stunting, excessive branching, from pale yellowing to deep yellowing, and small leaves. The genus
Begomovirus is a circular single - standard DNA virus which is exclusively being transmitted by whitefly (Bemisiatabaci) in a persistent circulative manner (Vasudeva and Sam Raj, 1948). This pest remained in the field during February to September except month of May and July. The 14.29, 7.14, 28.57, 0.0, 35.71, 0.0, 7.14 and 7.14 percent farmers visited in the month of February, March, April, May, June, July, August and September respectively to get the technical information for control of this pest.

As far as nature of damage is concerned, the nymph and adult both suck the sap from tender part and lower surface of leaves, secret honey dew and transmitted leaf curl viruses in the tomato crop.

Hence, this stage of the pest seems to be the weakest link in its life cycle for its control with the application of the available systemic/ neonicotinoids insecticides at the farmers level. Farmers does not try to find the weak link in the life cycle of an insect pest and go for insecticide application either as a preventive spray or as and when insect attack appears in the field. Under both the cases, the pest is not managed effectively.

\section{Incidence of Late blight disease (Phytophthora infestans)}

Late blight caused by Phytophthora infestans, is one of the most destructive diseases of tomato as well as potato worldwide, causing significant economic losses annually (Nowicki et al., 2012).

Late blight incidence was found in the month of May and June. In the month of May and June the 50.0 and 50.0 percent farmers arrived in the KVK for disease diagnosis. Timely diagnosis and proper management strategies are necessary for the tomato farmers. 


\section{Infestation of fruit borer (Helicoverpa armigera)}

The quantity and quality of tomato fruits are considerably affected by array of insect pests infesting at different stages of crop growth. Though there are dozens of pests on tomato, besides other insect pests causing considerable damage, fruit borer Helicoverpa armigera Hubner (Lepidoptera: Noctuidae) is the serious one which causes considerable losses in quantity as well as quality of tomato fruits. The young larvae of $H$. armigera feed on flower buds and tender foliage while mature larvae bore in to circular holes in the fruit and eat the inner content resulting yield reduction (Rath and Nath, 1997). This pest remained in the field during March and April month in the area, the 66.67 and 33.33 percent farmers enquiring diagnosis and management of the fruit borer.

\section{Chilli and Brinjal}

Result (Table 4) showed that chilli and brinjal crop was more affected by leaf curl and shoot and fruit borer respectively as farmers enquired for control of these pests. Percent value of sample diagnosed during the month of March, April, May, June, July, August, September, October, November and December was 10.0, 10.0, 0.0, 6.67, 8.34, $23.33,38.33,0.0$ and 3.33 respectively.

\section{Leafcurl viruses in Chilli}

Chilli pepper or hot pepper (Capsicum anпиит L.) is an important spice and crop of family solanaceae. Chilli is susceptible to various pathogens involving viruses, which cause heavy production losses. So far 65 viruses have been reported throughout the world including begomo viruses causing chilli leaf curl virus disease (ChiLCVD) (Thakur et al., 2017).
ChiLCVD is the most destructive virus disease in term of incidence and yield loss. The disease can be identified by typical upward leafcurling, crinkling, puckering and reduction in leaf area along with stunting of whole plants. It is transmitted by the whitefly Bemisia tabaci in persistent manner.

Leaf curl disease remained in the chilli crop during March to November except may, July and October. The farmers were enquired for diagnosis and management of white fly transmitted leaf curl viruses disease was 20.0, $20.0,13.33,13.33,26.66$ and 6.66 percent in the month of March, April, June, August, September and November respectively. A leaf curl virus is the major challenge and limiting factor of chilli production in farmers field in the areas.

\section{Shoot and fruit borer in brinjal}

Brinjal shoot and fruit borer, Leucinodes orbonalis Guenee is a serious insect pest of brinjal in all brinjal growing countries (Chakraborthi and Sarkar, 2011, Datta et al., 2011).The caterpillar does the damage in the brinjal crop, when it attack the terminal shoots, the growing points are killed and when it attack the fruits, it damage the fruits development by making feeding tunnels inside (CABI, 2007). It was noticed that damage the crop by borer was found July to September. The 16.67, 33.33 and 50.0 percent farmers were enquired for diagnosis the sample and control measures of shoot and fruit borer in the month of July, August and September respectively. This pest is again of great concern and is difficult to control at the farmers level as well as pesticides dealers level, who mainly advise the farmers to go for insecticidal spray. It can not be controlled as it hide in the growing tips of shoot or in the fruits. Proper diagnosis and nature of damage are required for effective control of this pest. 


\section{Fruit crops}

\section{Incidence of leaf curl in papaya}

Papaya leaf curl disease is one of most serious threat to papaya cultivation in most of the papaya growing regions. Papaya leaf curl disease was first reported in India in 1939 (Thomas and Krishnaswamy, 1939) caused by begomovirus, Papaya leaf curl virus (PaLCV), infected papaya developed symptoms such as downward curling of leaves, twisted petioles, vein enation and stunting. Diseased plants produced small and distorted fruits that tend to fall prematurely. Whitefly could transmit the virus in the papaya crop. The $12.5,75.0$ and 12.5 percent farmers were enquired for diagnosis the disease sample and control measures of leaf curl in the month of June, July and August respectively (Table 5).

\section{Infestation of mealy bug in guava}

Guava Mealy bug (Ferrisia virgate CK1l.) is one of the most commonly occurring pests found on the fruit crops causing damage to guava and several host plants (Wabale et al., 2010). Mealy bug (both nymph and adult) damage the plants by inserting their threadlike mouth parts into any part of the plant and sucking out sap (Frank, 2011). Both nymphs and adults females of these Mealy bugs suck cell sap from different parts of the plant like the leaves, twinges, tender shoots, branches and fruits thereby reducing the vigor of plant as well as the drying up the tender shoots. They excrete honeydew, a sweet sticky liquid on which sooty moulds often grow causing infested plants to turn black. The 40.0, 20.0, 20.0 and 20.0 percent farmers were visited for diagnosis of the mealy bug sample and control measures in the month of March, May, August and September respectively in guava crop and also the 16.67, 33.33 and 50.0 percent farmers were enquiring about mealy bug infestation on Jack fruit crops in the month of July, August and September respectively (Table 5). The control of these mealy bug pests was very challenging as farmers field level, proper diagnosis was essential for effective management.

\section{Incidence of canker in citrus crop}

Citrus canker is a highly damaging disease of citrus crops caused by the bacterium Xanthomonas citri subsp. citri. The disease causes small, round bristle-like formation of leaves, branches, stems, new shoots and fruits. The canker lesions can develop within seven days of infection on leaves. Fruit are susceptible up to 90 days after petalfall. Young plants and seedling are more susceptible to citrus canker.

The 25.0, 25.0, 25.0 and 25.0 percent farmers were visited the centre for disease diagnosis and management of cancer in the month of February, April, August and October respectively (Table 5).

Farmers were not aware about the diagnosis and control of the disease. Citrus canker decreases fruit quality and yield. The disease leads to defoliation, twig dieback, blemished fruit and premature fruit drop. In severe cases, it can cause tree death.

In conclusion, plant health diagnosis is a unique initiatives tried by the KVK to link farmers with the scientific information, farmers realizing benefits from this service, there is a growing demand for the services of plant health diagnosis. There is need for adopting innovative strategies and more importantly adopting multipronged initiative and timely diagnostic and management strategies from plant health diagnosis to combat biotic and a biotic stresses, manage plant health mitigate losses. 
Table.1 Percent farmers visited at KVK for Apiary management (Average of 04 Yrs 2014-2018)

\begin{tabular}{|l|c|c|c|c|c|c|c|c|c|c|c|c|c|c|}
\hline Enterprises & $\begin{array}{c}\text { Total } \\
\text { farmers }\end{array}$ & Jan & Feb & Mar & Apr & May & June & July & Aug & Sep & Oct & Nov & Dec & $\begin{array}{c}\text { \% } \\
\text { Farmers }\end{array}$ \\
\hline $\begin{array}{l}\text { Apiary } \\
\text { insect pest, } \\
\text { predator } \\
\text { and disease }\end{array}$ & 103 & 13.59 & 3.88 & 1.94 & 5.82 & 7.77 & 2.91 & 9.71 & 15.53 & 10.68 & 8.74 & 11.15 & 10.68 & 100 \\
\hline
\end{tabular}

Table.2 Percent farmers visited at KVK for Potato crop (Average of 04 Yrs 2014-2018)

\begin{tabular}{|r|l|c|c|c|c|c|c|c|c|c|}
\hline S. No. & $\begin{array}{l}\text { Enterprises/ } \\
\text { Crop Problem }\end{array}$ & $\begin{array}{c}\text { Total } \\
\text { farmers }\end{array}$ & Aug & Sep & Oct & Nov & Dec & Jan & Feb & $\begin{array}{c}\text { \% } \\
\text { Farmers }\end{array}$ \\
\hline $\mathbf{1}$ & $\begin{array}{l}\text { Preventing } \\
\text { measures before } \\
\text { sowing }\end{array}$ & 04 & 50.0 & 0.0 & 50.0 & 0.0 & 0.0 & 0.0 & 0.0 & 5.48 \\
\hline $\mathbf{2}$ & $\begin{array}{l}\text { Late blight } \\
\text { incidence }\end{array}$ & 38 & 0.0 & 0.0 & 5.26 & 42.11 & 10.53 & 34.21 & 7.89 & 52.05 \\
\hline $\mathbf{3}$ & $\begin{array}{l}\text { White fly (Leaf } \\
\text { curl disease) }\end{array}$ & 31 & 0.0 & 0.0 & 3.23 & 16.13 & 6.73 & 61.29 & 9.67 & 42.47 \\
\hline
\end{tabular}

Table.3 Percent farmers visited at KVK for Tomato crop (Average of 04 Yrs 2014-2018)

\begin{tabular}{|c|l|l|l|l|l|l|l|l|l|l|l|}
\hline S. No. & $\begin{array}{l}\text { Enterprises/ } \\
\text { Crop Problem }\end{array}$ & $\begin{array}{l}\text { Total } \\
\text { farmers }\end{array}$ & Feb & Mar & Apr & May & June & July & Aug & Sep & \% Farmers \\
\hline $\mathbf{1}$ & $\begin{array}{l}\text { White fly (Leaf } \\
\text { curl disease) }\end{array}$ & 14 & 14.29 & 7.14 & 28.57 & 0.0 & 35.71 & 0.0 & 7.14 & 7.14 & 73.68 \\
\hline $\mathbf{2}$ & $\begin{array}{l}\text { Late blight } \\
\text { incidence }\end{array}$ & 02 & 0.0 & 0.0 & 0.0 & 50.0 & 50.0 & 0.0 & 0.0 & 0.0 & 10.53 \\
\hline $\mathbf{3}$ & Fruit borer & 03 & 0.0 & 66.67 & 33.33 & 0.0 & 0.0 & 0.0 & 0.0 & 0.0 & 15.79 \\
\hline & Total & 19 & 4.76 & 24.60 & 37.30 & 16.67 & 11.90 & 0.0 & 2.38 & 2.38 & 100.0 \\
\hline
\end{tabular}

Table.4 Percent farmers visited at KVK for Chilli and Brinjal crops (Average of 04 Yrs 20142018)

\begin{tabular}{|c|l|l|l|l|l|l|l|l|l|l|l|l|}
\hline S. No. & $\begin{array}{l}\text { Enterprises/ } \\
\text { Crop Problem }\end{array}$ & $\begin{array}{l}\text { Total } \\
\text { farmers }\end{array}$ & Mar & Apr & May & June & July & Aug & Sep & Oct & Nov & $\begin{array}{l}\text { \% } \\
\text { Farmers }\end{array}$ \\
\hline $\mathbf{1}$ & $\begin{array}{l}\text { White fly (Leaf } \\
\text { curl disease) in } \\
\text { Chilli }\end{array}$ & 15 & 20.0 & 20.0 & 0.0 & 13.33 & 0.0 & 13.33 & 26.66 & 0.0 & 6.66 & 71.43 \\
\hline $\mathbf{2}$ & $\begin{array}{l}\text { Shoot and Fruit } \\
\text { borer in Brinjal }\end{array}$ & 06 & 0.0 & 0.0 & 0.0 & 0.0 & 16.67 & 33.33 & 50.0 & 0.0 & 0.0 & 28.57 \\
\hline & Total & 21 & 10.0 & 10.0 & 0.0 & 6.67 & 8.34 & 23.33 & 38.33 & 0.0 & 3.33 & 100.0 \\
\hline
\end{tabular}


Table.5 Percent farmers visited at KVK for fruit crops (Average of 04 Yrs 2014-2018)

\begin{tabular}{|c|l|c|c|c|c|c|c|c|c|c|c|c|}
\hline S. No. & $\begin{array}{l}\text { Enterprises/ } \\
\text { Crop problem }\end{array}$ & $\begin{array}{c}\text { Total } \\
\text { farmers }\end{array}$ & Feb & Mar & Apr & May & June & July & Aug & Sep & Oct & $\begin{array}{c}\text { \% } \\
\text { Farmers }\end{array}$ \\
\hline $\mathbf{1}$ & Papaya leaf curl & 08 & 0.0 & 0.0 & 0.0 & 0.0 & 12.5 & 75.0 & 12.5 & 0.0 & 0.0 & 34.79 \\
\hline $\mathbf{2}$ & $\begin{array}{l}\text { Guava mealy } \\
\text { bug }\end{array}$ & 05 & 0.0 & 40.0 & 0.0 & 20.0 & 0.0 & 0.0 & 20.0 & 20.0 & 0.0 & 21.74 \\
\hline $\mathbf{3}$ & $\begin{array}{l}\text { Jack fruit mealy } \\
\text { bug }\end{array}$ & 06 & 0.0 & 0.0 & 0.0 & 0.0 & 0.0 & 16.67 & 33.33 & 50.0 & 0.0 & 26.08 \\
\hline $\mathbf{4}$ & Citrus Canker & 04 & 25.0 & 0.0 & 25.0 & 0.0 & 0.0 & 0.0 & 25.0 & 0.0 & 25.0 & 17.39 \\
\hline & Total & 23 & 6.25 & 10.0 & 6.25 & 5.0 & 3.33 & 22.92 & 22.71 & 17.5 & 6.25 & 100.0 \\
\hline
\end{tabular}

Acknowledgements

Authors are thankful to authorities of RVSKVV, Gwalior and ICAR, New Delhi for providing necessary facilities.

\section{References}

CABI (2007). Crop protection compendium. CABI International. (Available at:http://www.cabicompendium.org/cp c).

Chakraborthi, S and Sarkar P.K. (2011). Management of Leucinodes orbonalis Guenee on egg plant during the rainy season in India. J. Protect. Res., 51:325-328.

Chaudhary, O.P. (2014). Present status of pests and diseases of honey bee Apismelifera L. in India and innovations in their management. In workshop on promotion of Honey bee keeping in Haryana held on June 24, 2014.

Dutta, P., Singha, A.K., DAS, P. and Kalita S. (2011). Management of brinjal fruit and shoot borer, Leucinodes orbonalis in agro-ecological condition of West Tripura. Scholarly J. Agric. Sci., 1:1619.

FAO (2006).Honey bee diseases and pests: a practical guide. Agricultural and Food Engineering Technical Report No4.pp42

Frank, S.D. (2011) Mealy bugs.
http://mrec.ifas.ufl.edu./Iso/mealy bugs, htm date: 15/5/2013

Gottwald, T.R. Graham, J.H. and Schubert, T.S. (2002). Citrus canker: The pathogen and its impact. Online. Plant Health progress DOI:10.1094/PHP2002-0812-01-RV.

Hachiro Shimanuki and David A. Knox (2000). Diagnosis of Honey bee diseases. USDA Agriculture Hand book No.AH-690, 61pp.

Kumar Pradeep and Kumar Manish (2018). Leaf Curl Disease: A Significant Constraint in the Production of Tomato in India. http://dx.doi.org/10.5772/intechopen.7 6049

Oerke E L, Debne H W, Schonbeck F and Weber A (1994). Crop production and crop protection, Elsevier, Amsterdan, 1994.

Rath P.C. and Nath P. (1997). Screening of some tomato genotypesfor susceptibility to the fruit borer, $H$. armigera (Hub.) at Varanasi. Veg. Sci., 24(2):153-156.

Sakpal S.D., Sonkamble M.M. and Gaikwad B.B. (2018). Seasonal incidence of tomato fruit borer, Helicoverpa armigera (Hubner) on tomato, Lycopersicon esculentum (Mill)under protected cultivation. Journal of Entomology and Zoology Studies, 6(4): 1911-1914.

Singh Gurmeet, Kaur Gagandeep, Sharma 
Manoj, Kaur Gurmeet and Singh Gobinder (2013). Use and availability of recommended pesticides in district Kapurthala. J. Krishi Vigyan 2(1):6472.

Thakur H., Jindal S.K., Sharma A. and Dhaliwal M.S. (2017). Chillileaf curl virus disease: a serious threat for chilli cultivation. Journal of plant disease and Protection. https://doi.org/10.1007/s41348-0180146-8.

Vasudeva R.S. and Sam Raj J. (1948). A leaf curl disease of tomato.
Phytopathology. 38:364-369.

Villamizar Sonia and Carlos Caicedo Juan (2019). Biological control of Citrus Canker: New Approach for disease control. DOI: 10.5772/intechopen. 88000

Wabale, A.S., Jadhav, V.G., vane, A.D. and Nale, B.V. (2010). Efficacy of Balanitesa egyptiaca (L.) Delli Leaf Extract against Mealy bug (Ferrisia virgate CKll). Asian journal of Experimental Biological Sciences, SPL.: 112-114.

\section{How to cite this article:}

Ashok S. Yadav, S.P. Singh and Pradyumn Singh. 2020. Diagnosis of Insect Pests and Diseases of Apiary, Vegetable and Fruit Crops. Int.J.Curr.Microbiol.App.Sci. 9(07): 1284-1292. doi: https://doi.org/10.20546/ijcmas.2020.907.147 